\title{
Analityczno-numeryczna analiza spawania laserowego płaskowników smukłych
}

\section{Analytical-numerical analysis of laser welding of thin flat bars}

\section{Streszczenie}

W pracy przedstawiono model analityczno-numeryczny oraz analizę zjawisk cieplnych, przemian fazowych i zjawisk mechanicznych towarzyszących spawaniu techniką laserową smukłych elementów płaskich. Do rozwiązania zagadnienia przewodzenia ciepła zastosowano metodę funkcji Greena. Model szacowania udziału faz oraz ich kinetyki oparto na wykresie spawalniczym ciągłego chłodzenia (CTPc-S). Udziały faz metalurgicznych powstających podczas ciągłego nagrzewania i chłodzenia (austenit, perlit lub bainit) wyznaczano równaniem Johnsona-Mehla i Avramiego. Do wyznaczania tworzącego się martenzytu wykorzystano zmodyfikowane równanie Koistinena i Marburgera. Naprężenia i odkształcenia wyznaczono z rozwiązania metodą elementów skończonych równań równowagi w formie prędkościowej. Uwzględniono odkształcenia cieplne, strukturalne, plastyczne oraz odkształcenia indukowane przemianami fazowymi. Do wyznaczania odkształceń plastycznych zastosowano warunek plastyczności Hubera-Misesa ze wzmocnieniem izotropowym, natomiast odkształcenia plastyczne indukowane przemianami fazowymi obliczano formułą Leblonda. Dokonano analizy składu fazowego i naprężeń towarzyszących spawaniu doczołowemu elementów wykonanych z niskowęglowej spawalnej stali (S235). Analizę przeprowadzono dla dwóch wersji spawania: pojedynczą wiązką laserową oraz podwójnymi wiązkami, z których jedna została użyta do podgrzewania wstępnego, a druga do spawania.

Słowa kluczowe: spawanie laserowe; przemiany fazowe; zjawiska cieplne i mechaniczne

\begin{abstract}
In the paper an analytical-numerical model and the analysis of thermal phenomena, phase transformations and mechanical phenomena occur in laser welding of thin flat bars were presented. To solve the heat transfer equation, the method of Green's function was used. To calculate the phase fractions and their kinetics the model based on the analysis of the continuous cooling diagram for the welding (CCT) is used. Phase fractions which occur during the continuous heating and cooling (austenite, pearlite or bainite) are described by Johnson-Mehl-Avrami (JMA) formula. To determine the formed martensite the modified KoistinenMarburger (KM) equation is used. The stress and strain are determined by the solution of the equilibrium equations in the rate form using finite element method. In the model the thermal, structural, plastic strains and induced plasticity are taken into account. To calculate the plastic strains the Huber-Mises plasticity condition with isotropic hardening is used. Whereas to determine transformations induced plasticity the modified Leblond model is applied. The analysis of the phase content and stress state which occur during the butt welding of elements made of low carbon steel (S235) were performed. The calculations were carried out for the two cases of welding: a single laser beam and a double laser beam, where first was a preheating source and the second the main welding source.
\end{abstract}

Keywords: laser welding; phase transformations; thermal and mechanical phenomena

\section{Wstęp}

Spawanie laserowe jest obecnie bardzo często stosowaną technologią. Brak jest jednak kompleksowych modeli numerycznych pozwalających na wiarygodną ocenę zjawisk towarzyszących takiemu spawaniu. Duże prędkości spawania oraz specyficzny kształt spoiny, jako charakterystyczne cechy spawania laserowego, są przyczynami występowania zjawisk niespotykanych w konwencjonalnych metodach spawania, bowiem spawanie laserowe prowadzone jest źródłami ciepła o dużych mocach. W otoczeniu tych źródeł występuje wysoka temperatura oraz znaczne jej gradienty $[1 \div 6]$. Temperatura i przemiany fazowe $w$ elementach spawanych są przyczyną generowania się znaczących odkształceń cieplnych i strukturalnych, a w konsekwencji naprężeń chwilowych i własnych $[1,3,7]$.

Mgr inż. Joanna Wróbel, dr hab. inż. Adam Kulawik, prof. PCz; prof. dr hab. inż. Adam Bokota

- Politechnika Częstochowska.

Autor korespondencyjny/Corresponding author. joanna.wrobel@icis.pcz.pl 
Większość prac poświęcona technologiom spawania laserowego skupia się na parametrach spawania oraz danych doświadczalnych, a istniejące modele numeryczne dotyczą wybranych zjawisk takich jak: pola temperatury, strefa przetopienia oraz strefa wpływu ciepła $[4 \div 6]$. Wprawdzie w pracach $[1,4,7]$ zaproponowano modele zjawisk mechanicznych spawania laserowego, ale nie uwzględniono w nich odkształceń indukowanych przemianami fazowymi.

Ocena wpływu zmian strukturalnych na odkształcenia i generujące się naprężenia w materiale spawanym mają duże znaczenie technologiczne. Naprężenia determinują własności mechaniczne i wytrzymałość złącza spawanego. Ocena taka jest możliwa dopiero wówczas, gdy istnieją informacje o przemianach fazowych występujących $w$ danym cyklu cieplnym, a tym samym o uzyskiwanej strukturze w spoinie i strefie wpływu ciepła. Modele numeryczne przemian fazowych i naprężeń umożliwiają uniknięcie kosztownych badań w uzyskiwaniu danych do optymalnego prowadzenia spawania techniką laserową.

\section{Model zjawisk cieplnych}

W modelowaniu zjawisk cieplnych wykorzystano równa-

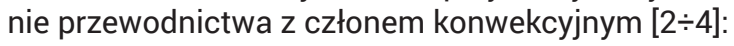

$$
a \nabla^{2} T(\mathbf{x}, t)-\frac{\partial T(\mathbf{x}, t)}{\partial t}+\operatorname{grad}(T(\mathbf{x}, t)) \cdot \mathbf{v}=-\frac{Q}{C}
$$

gdzie:

$\mathrm{T}=\mathrm{T}(\mathrm{x}, \mathrm{t})$ - temperatura $[\mathrm{K}]$;

a - współczynnik wyrównywania temperatury $\left[\mathrm{m}^{2} / \mathrm{s}\right]$;

$\mathrm{C}$ - właściwa pojemność cieplna $\left[\mathrm{J} /\left(\mathrm{m}^{3} \mathrm{~K}\right)\right]$;

$\mathrm{Q}$ - człon objętościowych źródeł ciepła, w którym uwzględnia się ciepło pochodzące od wiązki laserowej $\left[\mathrm{W} / \mathrm{m}^{3}\right]$;

v - wektor prędkości przesuwu wiązki [m/s];

$\mathrm{x}$ - wektor położenia rozważanej cząstki (punktu) [m]; $\mathrm{t}-\mathrm{czas}[\mathrm{s}]$.

Równanie (1) rozwiązano metodą zaproponowaną w pracy [2], polegającą na wykorzystaniu superpozycji funkcji Greena. Rozwiązanie to dotyczy geometrii i układu źródeł przedstawionych na rysunku 1.

Temperaturę w ustalonym punkcie determinują dwa źródła: jedno o rozkładzie Gaussowskim działające w odległości $\mathrm{x}^{\prime}=-\mathrm{d}$ od drugiego, liniowego o ustalonym zagłębieniu $\left(\mathrm{h}_{\mathrm{z}}\right)$. Zakłada się, że ustalony rozkład temperatury, w rozważanym

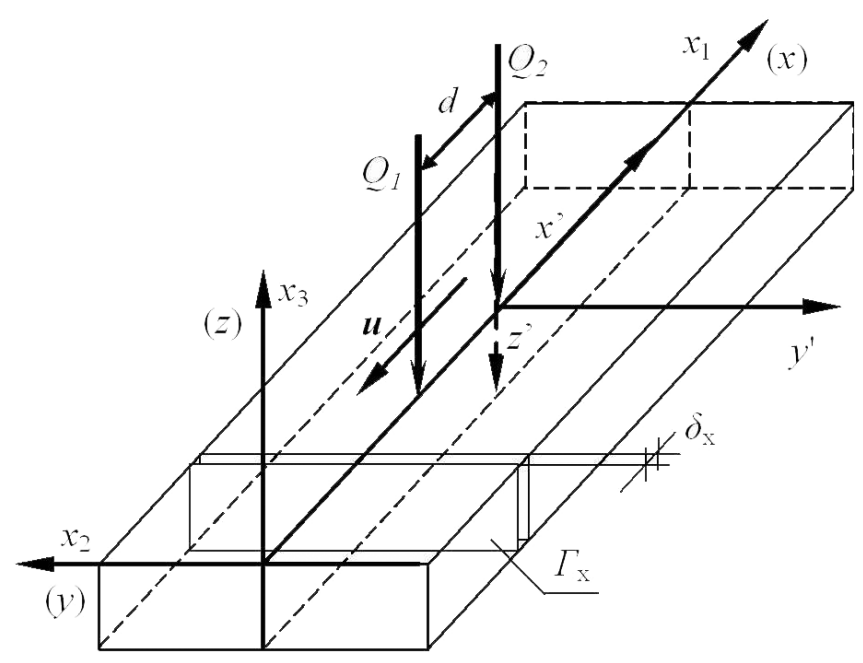

Rys. 1. Schemat rozważanej geometrii i położenie źródeł

Fig. 1. The scheme of the considered geometry and position of the sources obszarze, istnieje dla czasu t, a układ współrzędnych $\left\{x^{\prime}, y^{\prime}, z^{\prime}\right\}$ porusza się względem układu $\{x, y, z\}$ z prędkością $v=v(u, 0,0)$.

$$
\begin{aligned}
& Q_{1}\left(\mathbf{x}^{\prime}\right)=\frac{P_{1}(1-R)}{2 \pi r^{2}} \exp \left(-\frac{\left(x^{\prime}\right)^{2}+\left(y^{\prime}\right)^{2}}{2 r^{2}}-\beta\left|z^{\prime}\right|\right) \\
& Q_{2}=\frac{P_{2} H\left(z^{\prime}\right)}{h_{z}}, H\left(z^{\prime}\right)=\left\{\frac{1,-h_{z} \leq z^{\prime} \leq h_{z}}{0,\left|z^{\prime}\right|>h_{z}}\right.
\end{aligned}
$$

gdzie:

$P_{1}$ i $P_{2}-$ moce pochodzące od wiązek laserowych,

$\mathrm{R}$ - współczynnik odbicia,

$\beta$ - współczynnik absorpcji.

Po wykorzystaniu funkcji Greena i dodaniu warunku początkowego $\left(T_{0}\right)$ jest:

$$
\begin{aligned}
& T(\mathbf{x}, t)=\frac{1}{C} \int_{0}^{t} \int_{\Omega} Q_{1}\left(\mathbf{x}^{\prime}, t^{\prime}\right) G\left(\mid \mathbf{x}-\left(\mathbf{x}^{\prime}-d\right), t-t^{\prime}\right) d \Omega^{\prime} d t^{\prime}+ \\
& +\frac{1}{C} \int_{0}^{t} \int_{\Omega} Q_{2} G\left(\mathbf{x}-\mathbf{x}^{\prime} \mid, t-t^{\prime}\right) d \Omega^{\prime} d t^{\prime}+T_{0}
\end{aligned}
$$

Całkowanie (4) po współrzędnych przestrzennych z uwzględnieniem (2) i (3) daje półanalityczne rozwiązanie równania (1). W postaci jawnej rozwiązanie to przedstawiono w pracy [2]. Wymaga ono numerycznego całkowania po czasie. Całkowanie to przeprowadzano metodą trapezów.

\section{Przemiany fazowe w stanie stałym}

Model kinetyki przemian fazowych w stanie stałym oparto na spawalniczym wykresie chłodzenia ciągłego (CTPc-S) dla stali S235, zbudowanego dla szybkości chłodzenia w zakresie temperatur $800 / 500^{\circ} \mathrm{C}[4,7,8]$.

Udział austenitu powstającego $\mathrm{w}$ procesie nagrzewania wyznaczano korzystając z formuły Avramiego $[1,9,10]$. Udziały faz powstałych z austenitu w procesie chłodzenia są determinowane temperaturą i szybkością chłodzenia w przedziale temperatury $T_{8 / 5}$. Udział nowej fazy, takiej jak bainit, ferryt czy perlit wyznaczano również wzorem stosowanym do przemian dyfuzyjnych (formułą Avramiego) uwzględniając w nim istniejące już udziały wcześniej powstałych faz, natomiast udział martenzytu wyznaczano ze wzoru Koistinena-Marburgera, tzn.:

$$
\begin{aligned}
& \tilde{\eta}_{A}(T, t)=1-\exp \left(-b\left(t_{s}, t_{f}\right)(t(T))^{n\left(t_{s}, t_{f}\right)},\right. \text { nagrzewanie } \\
& \eta_{B F P}(T, t)=\eta_{m}\left(1-\exp \left(-b(t(T))^{n}\right)\right), \\
& \eta_{M}(T)=\eta_{m}\left(1-\exp \left(-\left(\left(M_{s}-T\right) /\left(M_{s}-M_{f}\right)\right)^{m}\right)\right)
\end{aligned}
$$

gdzie:

$\eta_{m}=\eta_{(.)}^{\%} \widetilde{\eta}_{A}$ dla $\tilde{\eta}_{A} \geq \eta_{(.)}^{\%}$ i $\eta_{m}=\widetilde{\eta}_{A}$ dla $\tilde{\eta}_{A}<\eta_{(.)}^{\%}$

$\eta_{(\cdot)}^{\%}$ - maksymalny udział fazy dla ustalonej szybkości chłodzenia ocenionej na bazie wykresu CTPc-S,

$\mathrm{b}\left(\mathrm{t}_{\mathrm{s}}, \mathrm{t}_{\mathrm{f}}\right)$ i $\mathrm{n}\left(\mathrm{t}_{\mathrm{s}}, \mathrm{t}_{\mathrm{f}}\right)$ - współczynniki wyznaczane z (5) z założeniem, że początkowy udział fazy to: $\eta_{s}\left(t_{s}\right)=0,01$, a maksymalna wartość udziału to: $\eta_{\mathrm{f}}\left(\mathrm{t}_{\mathrm{f}}\right)=0,99$,

$\tilde{\eta}_{\mathrm{A}}$ - udział powstałego austenitu w procesie nagrzewania (austenityzowania),

m - stała oszacowana eksperymentalnie. Dla rozważanej stali stała $m=10$, ustalona została dla temperatury początku przemiany martenzytycznej $\mathrm{M}_{\mathrm{s}}=410^{\circ} \mathrm{C}$ oraz temperatury zakończenia tej przemiany $\mathrm{M}_{\mathrm{f}}=220^{\circ} \mathrm{C}[6,8]$. 
Odkształcenia izotropowe od temperatury i przemian fazowych (odkształcenia strukturalne) wyznaczane są równaniem:

$$
d \varepsilon^{T P h}=\sum_{i=1}^{i=5} \alpha_{i} \eta_{i} d T-\operatorname{sign}(d T) \sum_{i=i}^{j=5} \varepsilon_{i}^{P h} d \eta_{i}
$$

gdzie:

$\mathrm{i}=\mathrm{A}, \mathrm{B}, \mathrm{F}, \mathrm{M}, \mathrm{P}$;

$a_{i}=a_{i}(T)$ - współczynniki termicznej rozszerzalności austenitu, bainitu, ferrytu, martenzytu i perlitu;

$\varepsilon_{\mathrm{i}}^{\mathrm{Ph}}=\varepsilon_{\mathrm{i}}^{\mathrm{Ph}}(\mathrm{T})$ - izotropowe odkształcenia od przemian fazowych: struktury wyjściowej w austenit, austenitu w bainit, ferryt, martenzyt bądź w perlit;

sign(.) - funkcja znaku.

Współczynniki rozszerzalności termicznej oraz izotropowe odkształcenia strukturalne przyjęto na podstawie badań przeprowadzonych na symulatorze cykli cieplnych oraz testowych symulacji odkształceń z wykorzystaniem (6) dla różnych szybkości chłodzenia rozważanej stali $[3,4]$.

\section{Zjawiska mechaniczne}

Informacje o naprężeniach towarzyszących spawaniu uzyskano, rozwiązując równania równowagi w formie prędkościowej, uzupełnione związkami konstytutywnymi oraz od-

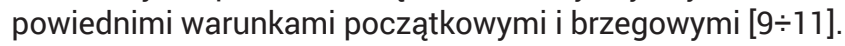

$$
\begin{aligned}
& \operatorname{div}(\dot{\boldsymbol{\sigma}}(\mathbf{x}, t))=0, \boldsymbol{\sigma}^{T}=\boldsymbol{\sigma} \quad \dot{\boldsymbol{\sigma}}=\mathbf{E} \circ \dot{\boldsymbol{\varepsilon}}^{\mathrm{e}}+\dot{\mathbf{E}} \circ \boldsymbol{\varepsilon}^{\mathrm{e}} \\
& \boldsymbol{\sigma}\left(\mathbf{x}, t_{0}\right)=\boldsymbol{\sigma}\left(\mathbf{x}, T_{s o l}\right)=\mathbf{0}, \boldsymbol{\varepsilon}\left(\mathbf{x}, t_{0}\right)=\boldsymbol{\varepsilon}\left(\mathbf{x}, T_{s o l}\right)=\mathbf{0}
\end{aligned}
$$

gdzie:

$\sigma=\sigma\left(\sigma_{\sigma \beta}\right)-$ tensor naprężenia,

$\mathrm{E}$ - tensor stałych materiałowych,

$\varepsilon^{\mathrm{e}}-$ tensor odkształceń sprężystych $\left(\varepsilon^{\mathrm{e}}=\varepsilon-\varepsilon^{\mathrm{p}}-\varepsilon^{\mathrm{TPh}}-\varepsilon^{\mathrm{tp}}\right)$,

$\varepsilon$ - tensor odkształceń całkowitych,

$\varepsilon^{\mathrm{p}}$ - tensor odkształceń plastycznych,

$\varepsilon^{\text {TPh }}$ - izotropowy tensor odkształceń cieplnych i od prze-

mian fazowych $\left(\varepsilon^{\mathrm{TPh}}=\varepsilon^{\top}+\varepsilon^{\mathrm{Ph}}\right)$,

$\varepsilon^{\text {tp }}$ - tensor odkształceń indukowanych przemianami fazowymi,

$\mathrm{T}_{\text {sol }}$ - temperatura solidusu.

Moduł Younga i moduł styczny uzależniono od temperatury natomiast granicę plastyczności, od temperatury i składu fazowego. Do wyznaczania odkształceń plastycznych wykorzystano prawo nieizotermicznego plastycznego

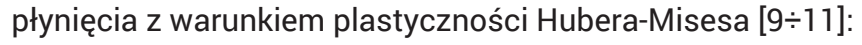

$$
f=\sigma_{e f}-Y\left(T, \sum \eta_{k}, \varepsilon_{e f}^{\mathrm{p}}\right)=0
$$

gdzie:

$\mathrm{f}$ - funkcja plastycznego płynięcia,

$\sigma_{\text {ef }}-$ naprężenie efektywne,

$Y=Y_{0}\left(T, \Sigma \eta_{k}\right)+Y_{H}\left(T, \varepsilon_{\text {ef }}^{p}\right)$ - naprężenie uplastyczniające dla materiału o składzie fazowym $\Sigma \eta_{\mathrm{k}}$ w temperaturze T oraz uplastycznieniu efektywnym $\left(\varepsilon^{\mathrm{p}} \mathrm{ef}\right)$,

$Y_{0}=Y_{0}\left(T, \Sigma \eta_{k}\right)$ - granica plastyczności,

$\mathrm{Y}_{\mathrm{H}}$ - nadwyżka wynikającą ze wzmocnienia materiału.

Odkształcenia indukowane przemianami fazowymi wyznaczano formułą Leblonda [12,13]:

$$
\dot{\boldsymbol{\varepsilon}}^{\mathrm{tp}}=\left\{\begin{array}{l}
0, \text { dla } \eta_{k} \leq 0.03, \\
-3 \sum_{k=2}^{k=5}\left(1-\eta_{k}\right) \varepsilon_{1 k}^{p h} \frac{\mathbf{S}}{Y_{1}} \ln \left(\eta_{k}\right) \dot{\eta}_{k}, \text { dla } \eta_{k}>0.03
\end{array}\right.
$$

gdzie:

$S$ - dewiator tensora naprężenia $\left(S=\sigma-\mid \sigma_{a a} / 3\right)$,

$\varepsilon^{\mathrm{ph}}{ }_{1 \mathrm{k}}$ - odkształcenia strukturalne przy przejściu z fazy wyjściowej (austenitu "1") na k-tą fazę,

$\mathrm{Y}_{1}$ - naprężenie uplastyczniające fazy wyjściowej (miękkiej, tzn. austenitu).
Ze względu na przyjętą geometrię obiektu do symulacji zjawisk mechanicznych związki konstytutywne przyjęto dla zmodyfikowanego płaskiego stanu odkształcenia spełniając uwarunkowania całkowe $[3,11]$ :

$$
\int_{\Gamma_{11}} \dot{\sigma}_{11} d \Gamma=\left.\dot{N}\right|_{\Gamma_{11},} \int_{\Gamma_{11}} \dot{\sigma}_{11} d \Gamma=0,\left(\dot{\varepsilon}_{11}\left(x_{1}, x_{2}\right) \neq 0\right)
$$

gdzie:

N - wypadkowa siła normalna działającą w przekroju $\Gamma_{x}$ (prostopadłym do osi $x=x_{1}$, rys. 1), pochodzącą od uwarunkowań brzegowych (w przypadkach uwarunkowań zapewniających zewnętrzną statyczną wyznaczalność jest ona równa zeru $(\mathrm{N}=0)$ i w symulacji numerycznej dokonano takiego założenia (por. 112)).

W modelu zjawisk mechanicznych założono, że w dowolnie wybranej warstwie o różniczkowej grubości $\delta_{x}=\delta_{x}(x)$ (rys. 1), ze względu na symetrię obciążenia cieplnego i od przemian fazowych, odkształcenia całkowite na kierunku prostopadłym do przekroju poprzecznego są różne od zera (niezależne od współrzędnych $x$ i y, $\varepsilon_{x}(x, y)=$ const $\neq 0$ ). Odkształcenia te obliczano z równania całkowego $\left(11_{2}\right)$ po podstawieniu związku konstytutywnego na $\sigma_{11}$. Niestety, taka modyfikacja modelu płaskiego stanu odkształcenia $\left(\varepsilon_{11} \neq 0\right)$ wymusza prowadzenia dodatkowego procesu iteracyjnego w każdej zmianie obciążenia [8].

Zagadnienie termosprężysto-plastyczności rozwiązano metodą elementów skończonych (zadanie 2D dla każdej warstwy o grubości $\delta_{x}$ ), a w iteracji szacowania odkształceń plastycznych wykorzystano zmodyfikowany algorytm Newtona-Raphsona [10,11].

\section{Przykłady obliczeń}

Przeprowadzono symulację spawania laserowego ze wstępnym podgrzaniem i bez- wyznaczając pola temperatury, udziały fazowe i naprężenia $\mathrm{w}$ elemencie prostopadłościennym o wymiarach $120 \times 20 \times 4 \mathrm{~mm}$, spawanym wiązką laserową (rys. 1). Współczynniki odbicia (R) i absorpcji ( $\beta$ ) przyjęto równe 0,3 i 150 odpowiednio (zalecane w pracy [2]). Średnice wiązek były równe 6 i 1,5 mm odpowiednio. Źródła ciepła o mocach: $\mathrm{P}_{1}=1,25, \mathrm{P}_{2}=1,6 \mathrm{~kW}$ przesuwały się z prędkością $36 \mathrm{~m} / \mathrm{godz}$. ( $1 \mathrm{~cm} / \mathrm{s})$ i były oddalone od siebie o d=6 mm (rys. 1). W przypadku symulacji bez podgrzewania moc źródła była równa 2,0 kW. Założono, że element wykonany jest z niskowęglowej stali spawalnej (S235), dla której: $a=7,0 \times 10^{-6} \mathrm{~m}^{2} / \mathrm{s}, \mathrm{C}=5,0 \times 10^{6} \mathrm{~J} /\left(\mathrm{m}^{3} \mathrm{~K}\right)$. Temperatura początkowa była równa $T_{0}=300 \mathrm{~K}$, a temperatury solidus i likwidus: $\mathrm{T}_{\text {Sol }}=1650 \mathrm{i}_{\text {Lik }}=1750 \mathrm{~K}$.

Uzyskane rozkłady temperatury stanu ustalonego (w przekroju wzdłużnym obszaru kontrolnego) przedstawiono na rysunku 2. Dla przyjętych warunków nagrzewania (moce i prędkość spawania) uzyskano porównywalny poziom maksymalnych temperatur ( 3000 K, rys. 2). Poza obszarem obliczeń $(120 \times 20 \times 4 \mathrm{~mm})$ przedłużono obiekt do $250 \mathrm{~mm}$ o wyjściowym przekroju poprzecznym. W części przedłużonej, pole temperatury (od 120 do $250 \mathrm{~mm}$ ) aproksymowano liniowo do $300 \mathrm{~K}$ (rys. 2b), tzn. do zadanej temperatury początkowej, aby uzyskane z symulacji naprężenia były naprężeniami własnymi.

$\mathrm{Na}$ wszystkich zamieszczonych rysunkach współrzędne przestrzenne odniesione są do przyjętej parametryzacji rozważanej geometrii (por. rys. 1).

Uzyskane udziały faz, ze wstępnym podgrzewaniem i bez -, (na przekroju poprzecznym) przedstawiono na rysunkach 5, 6 i 7. Rozkłady udziałów faz obcięto do $5 \mathrm{~mm}$, aby lepiej przedstawić uzyskane wyniki w spoinie i otoczeniu strefy wpływu ciepła. 

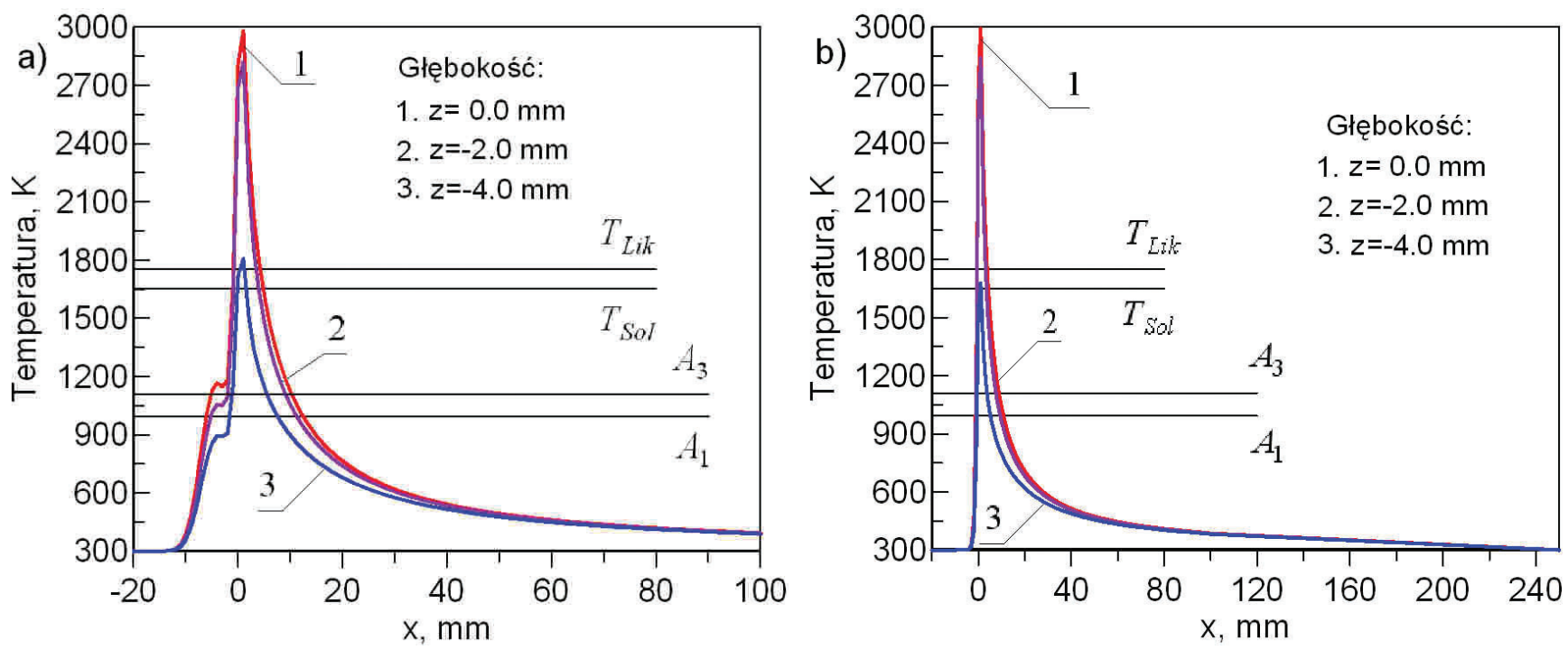

Rys. 2. Rozkłady temperatury, w płaszczyźnie działania wiązek laserowych, na powierzchniach: górnej ( $z=0)$, w połowie grubości ( $z=-2)$ i dolnej $(z=-4 \mathrm{~mm})$, a) z podgrzewaniem, b) bez podgrzewania

Fig. 2. The distribution of the temperature in the plane of laser beam, on the surfaces: upper $(z=0)$, in half of the thickness $(z=-2)$ and lower $(\mathrm{z}=-4 \mathrm{~mm})$, a) with preheating, b) without preheating

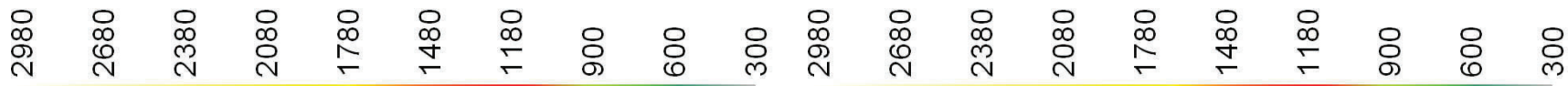
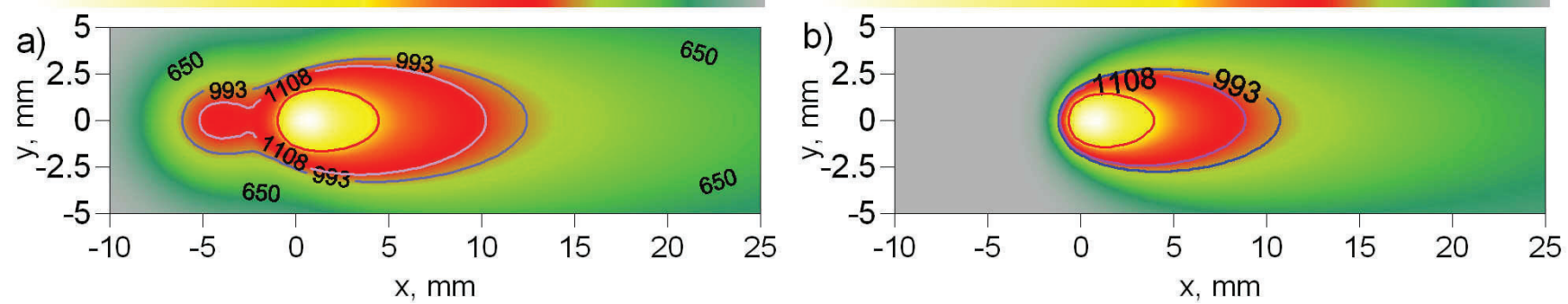

Rys. 3. Pola temperatury na powierzchni górnej $(z=0 \mathrm{~mm})$ płaskownika, a) z podgrzewaniem, b) bez podgrzewania. Zaznaczone izolinie temperatur to: $1700 \mathrm{~K}, \mathrm{Ac}_{3}$ i $\mathrm{Ac}_{1}$

Fig. 3. The temperature fields on the upper surface $(z=0 \mathrm{~mm})$ of the flat bar, a) with preheating, b) without preheating. The marked temperature isolates are: $1700 \mathrm{~K}, \mathrm{Ac}_{3}$ i $\mathrm{Ac}_{1}$

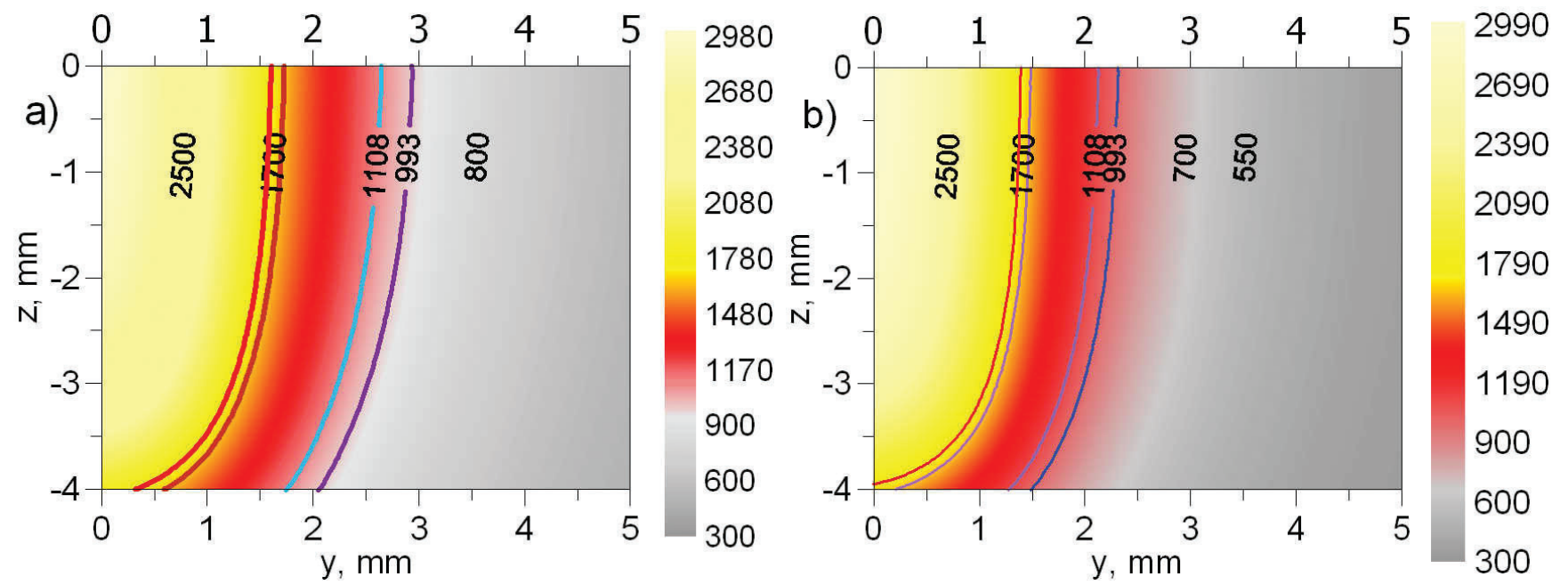

Rys. 4. Rozkłady (mapy) temperatury na przekroju poprzecznym, w płaszczyźnie maksymalnych szerokości przetopienia, a) ze wstępnym podgrzewaniem, b) bez wstępnego podgrzewania. Zaznaczone izolinie temperatur to: likwidus, solidus, $\mathrm{Ac}_{3}$ i $\mathrm{Ac}_{1}$

Fig. 4. The distribution of temperature in the cross section of the plane of the maximum width of fuzion zone, a) with preheating, b) without preheating. The marked temperature isolates are: liquidus, solidus, $A_{3}{ }_{3} A_{1}$ 

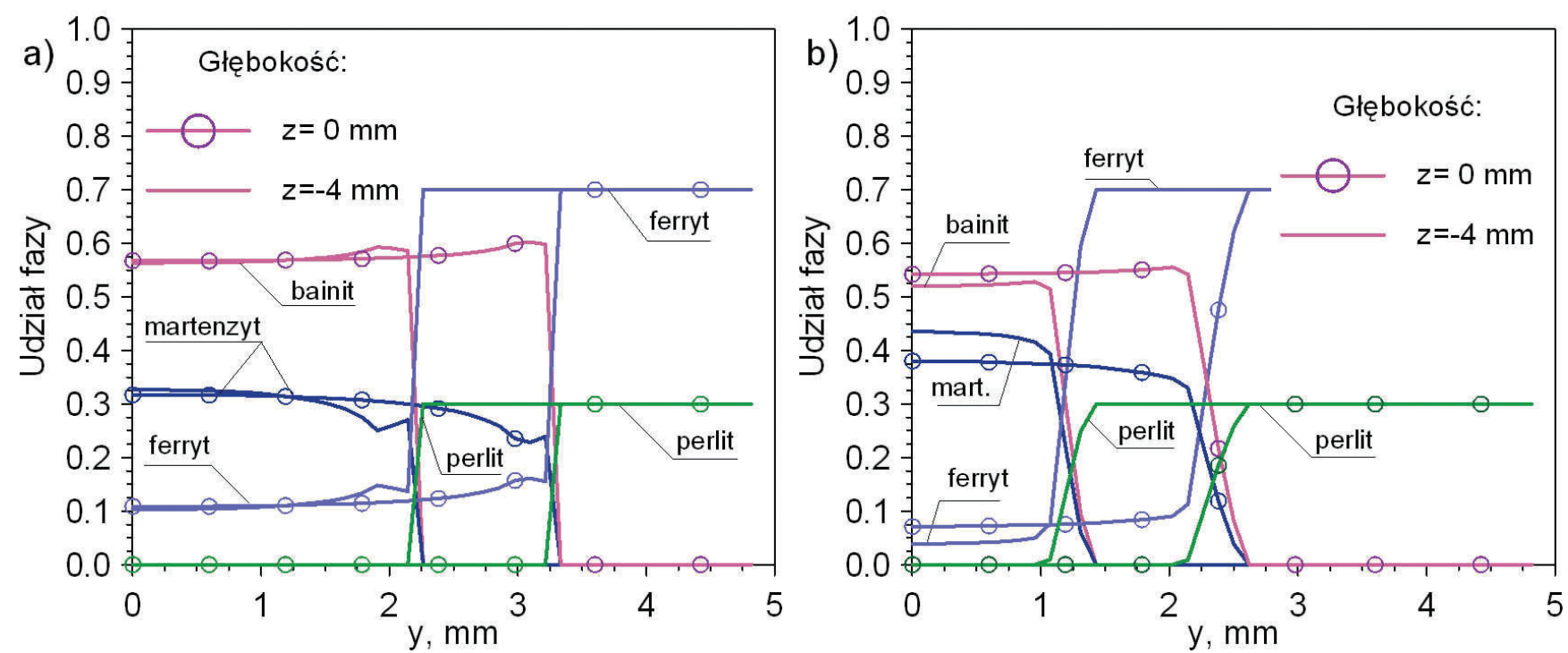

Rys. 5. Rozkłady udziału faz metalurgicznych na przekroju poprzecznym (przy powierzchni górnej $(\mathrm{z}=0)$ i powierzchni dolnej $(\mathrm{z}=-4 \mathrm{~mm})$ (rys. 1)), a) ze wstępnym podgrzewaniem, b) bez wstępnego podgrzewania

Fig. 5. The distribution of phase fractions in the cross sections (upper $(z=0)$ and lower surfaces $(z=-4 \mathrm{~mm})$ (Fig. 1)), a) with preheating, b) without preheating
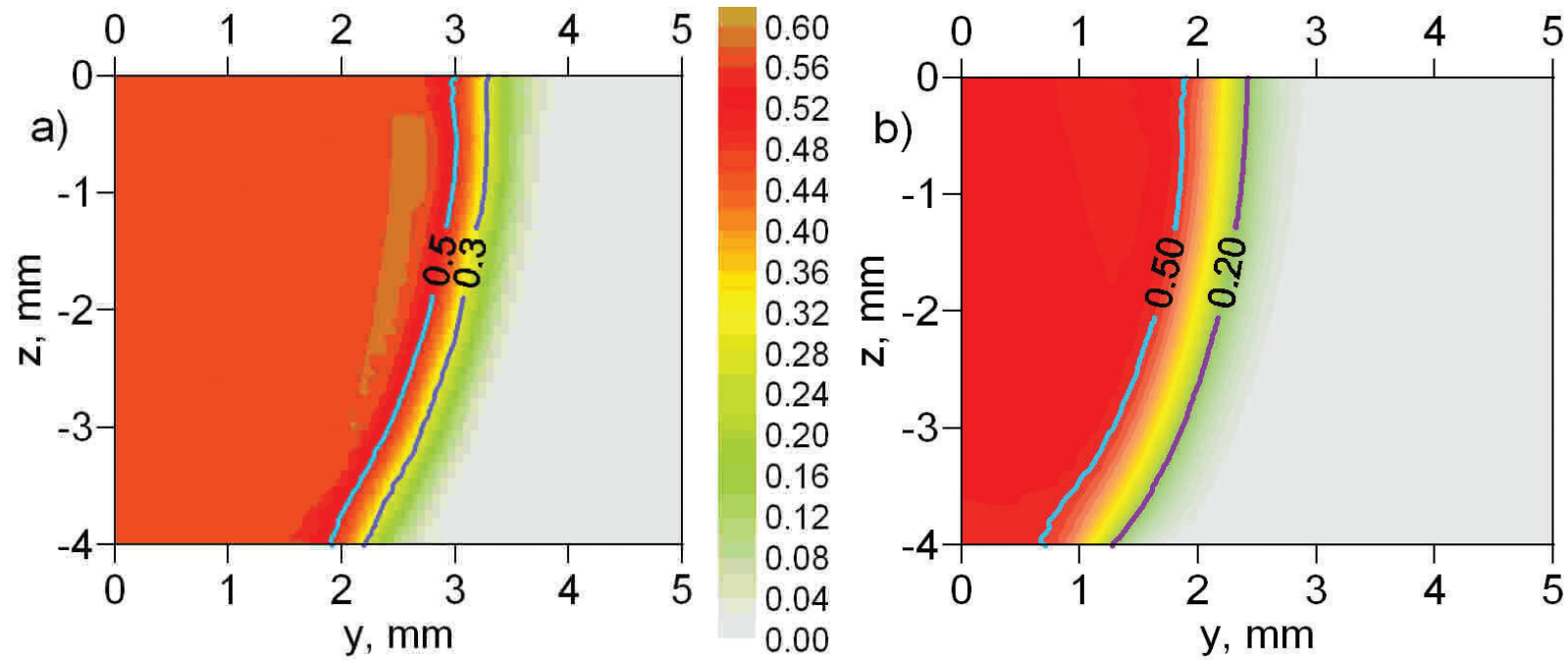

0.60

0.50

0.40

0.30

0.20

Rys. 6. Rozkłady (mapy) bainitu, a) ze wstępnym podgrzewaniem, b) bez wstępnego podgrzewania

Fig. 6. The distributions (maps) of bainite, a) with preheating, b) without preheating

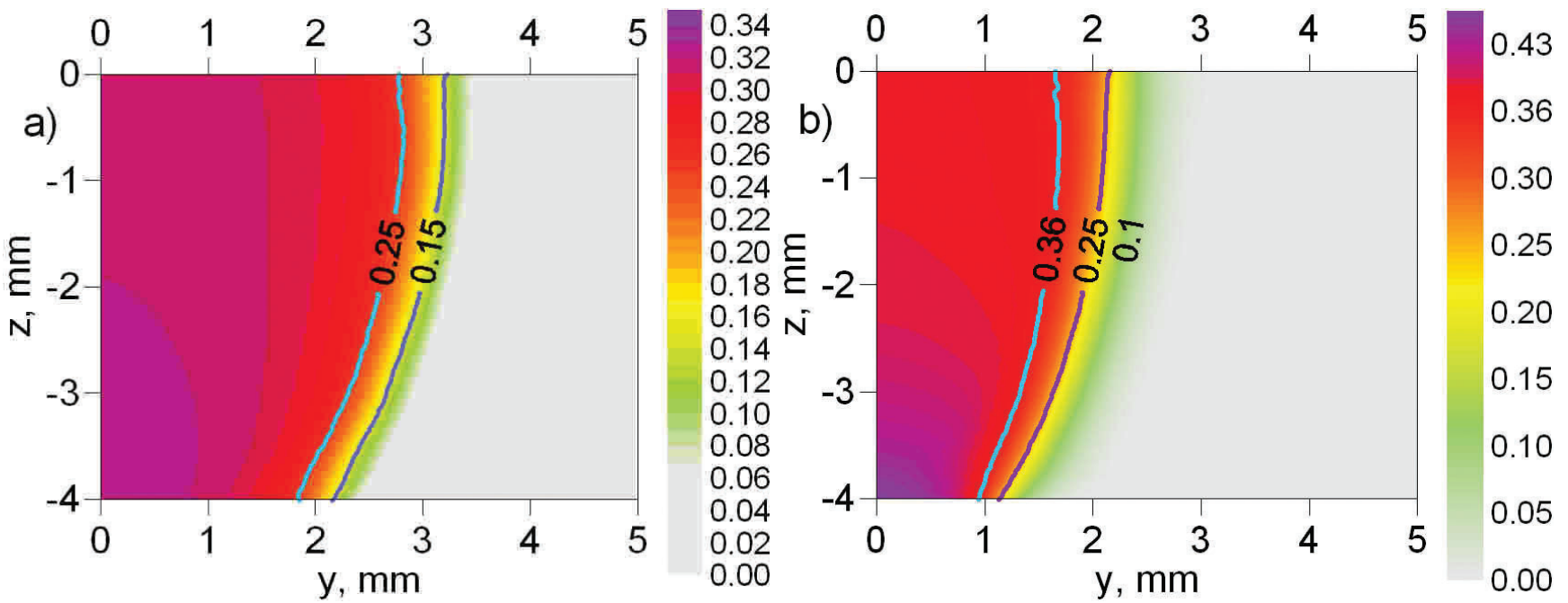

Rys. 7. Rozkłady (mapy) martenzytu, a) ze wstępnym podgrzewaniem, b) bez wstępnego podgrzewania

Fig. 7. The distributions (maps) of martensite, a) with preheating, b) without preheating 
Temperatura, $\mathrm{K}\left(Y_{0}\right)$

$1700150013001100 \quad 900 \quad 700 \quad 500 \quad 300$

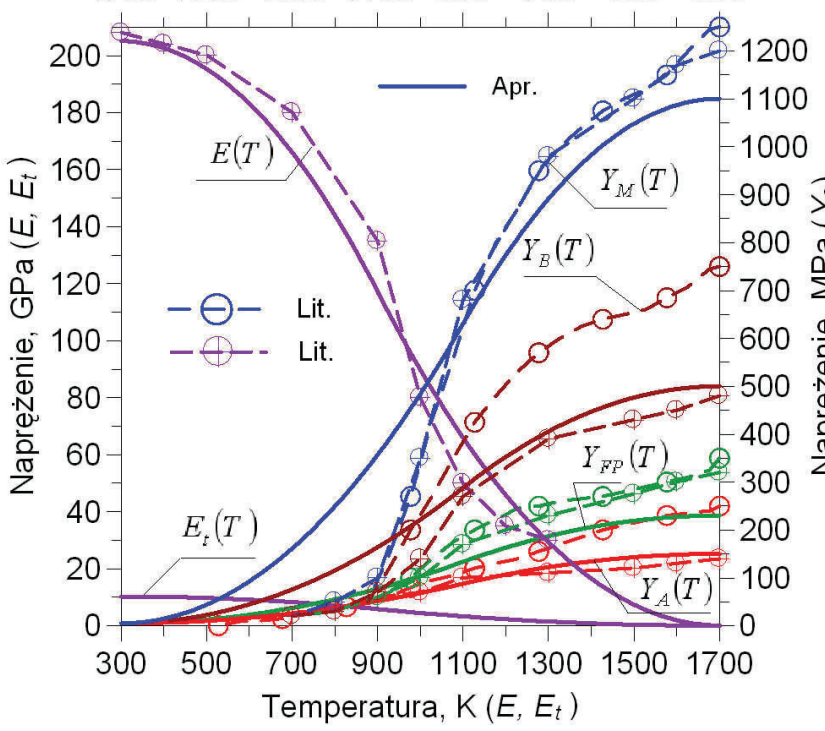

W symulacji zjawisk mechanicznych moduły Younga i styczny były równe: $E\left(T_{0}\right)=2,05 \times 10^{5}, E\left(T_{s}\right)=10 \mathrm{MPa}$ $\left(E_{t}(T)=0,05 \cdot E(T)\right)$. Granice plastyczności $\left(Y_{0}\left(T_{0}, \eta_{k}\right)\right)$ przyjęto równe: 150, 500, 230, 1100 i $230 \mathrm{MPa}$ odpowiednio dla austenitu, bainitu, ferrytu, martenzytu i perlitu, natomiast, $Y_{0}\left(T_{\text {sol, }} \eta_{k}\right)=5 \mathrm{MPa}$. Wielkości te ustalono na podstawie danych $w$ pracach $[7,9]$. W przedziale temperatury $\left[T_{0},\left(T_{\text {Sol }}+T_{L i k}\right) / 2\right]$ moduły Younga i styczny oraz granice plastyczności aproksymowano sklejanymi funkcjami kwadratowymi (stycznymi dla temperatury $900 \mathrm{~K}$, rys. 8).

Rozkłady (wykresy i mapy) naprężeń własnych uzyskane po spawaniu, ze wstępnym podgrzewaniem i bez -, przedstawiono na kolejnych rysunkach.

Po analizie wyników (rys. 9), rozkłady (mapy) naprężeń obcięto do $7 \mathrm{~mm}$, aby czytelniej przedstawić wyniki w otoczeniu strefy wpływu ciepła.

Rys. 8. Wykresy przyjętych funkcji aproksymujących $E(T), E_{t}(T)$ i $Y_{0}\left(T, \eta_{k}\right)$ Fig. 8. The diagrams of the assumed approximation functions $E(T), E_{t}(T)$ i $Y_{0}\left(T, \eta_{k}\right)$
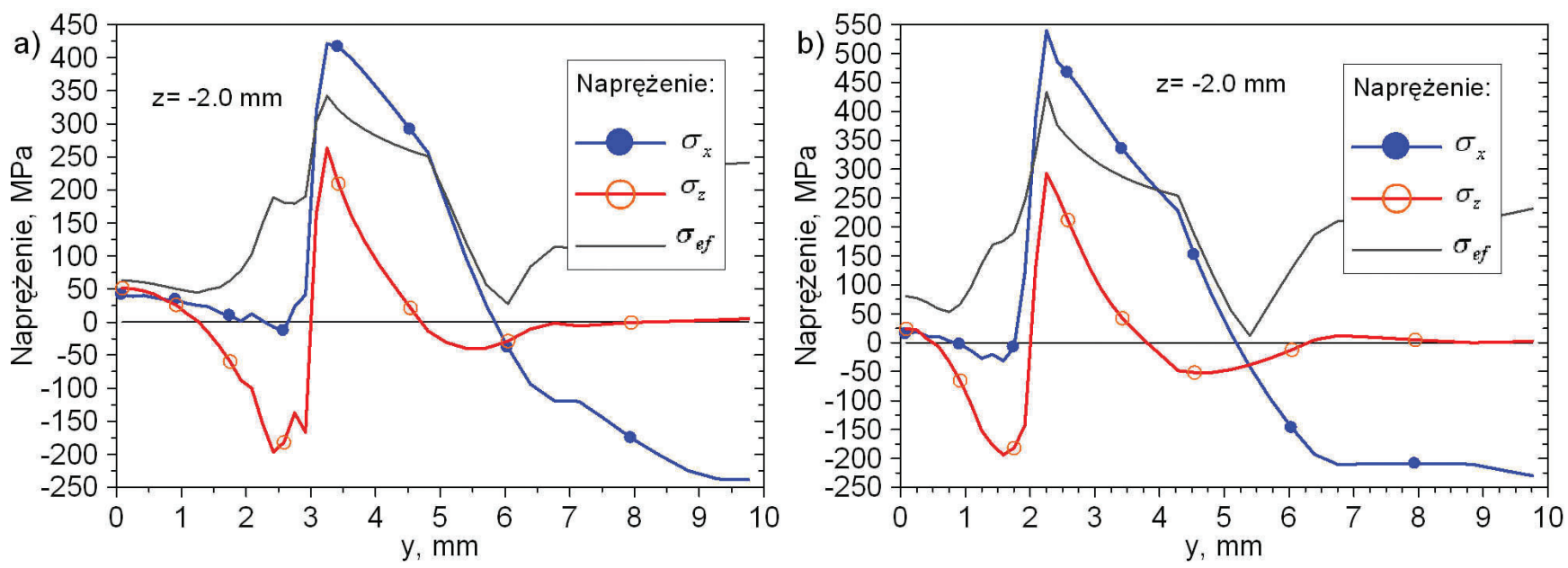

Rys. 9. Rozkłady (wykresy) na przekroju poprzecznym naprężeń po spawaniu (na połowie grubości płaskownika ( $\mathrm{z}=-2 \mathrm{~mm})$, (rys. 1)), a) z podgrzewaniem, b) bez podgrzewania

Fig. 9. The distributions of stresses in the cross section after the welding (in half of the thickness $(z=-2 \mathrm{~mm})$, (Fig. 1)), a) with preheating, b) without preheating
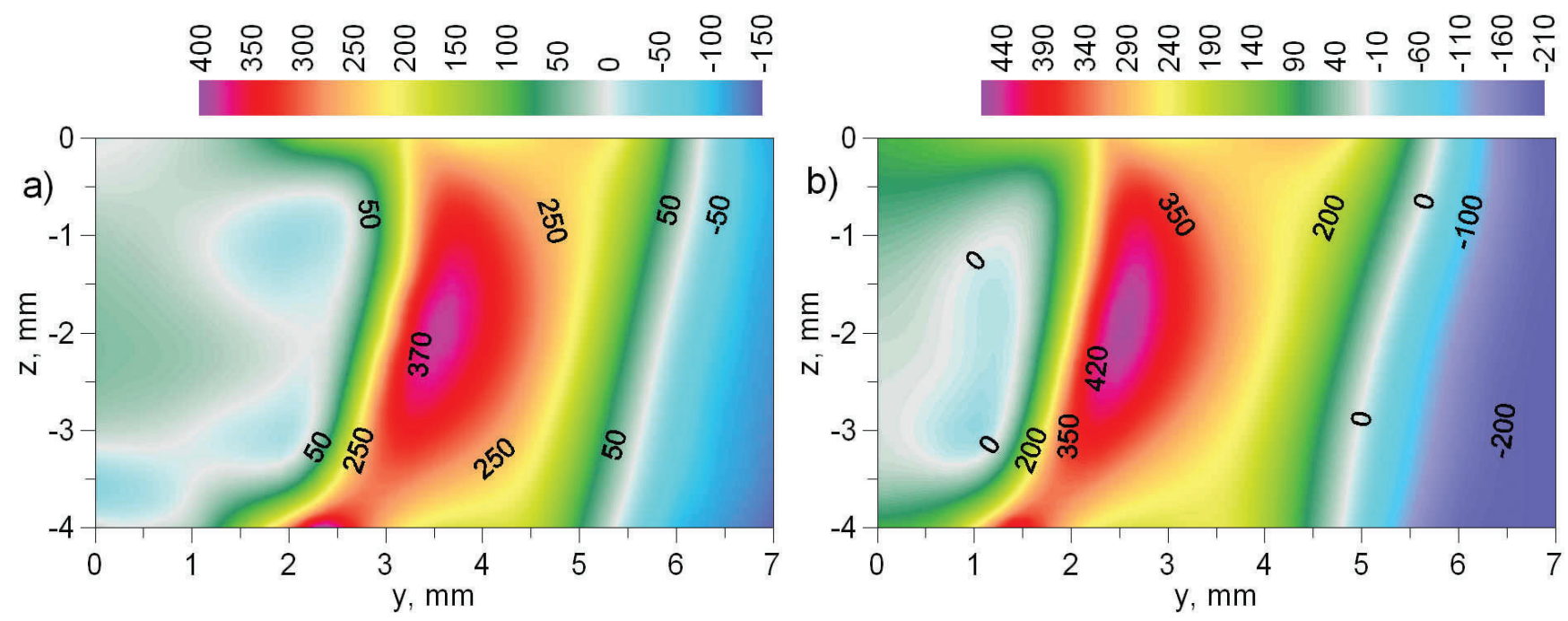

Rys. 10. Rozkłady (mapy) naprężeń osiowych $\left(\sigma_{x}\right)$ na przekroju poprzecznym, a) z podgrzewaniem, b) bez podgrzewania

Fig. 10. The distributions (maps) of axial stresses $\left(\sigma_{x}\right)$ in the cross sections, a) with preheating, b) without preheating 

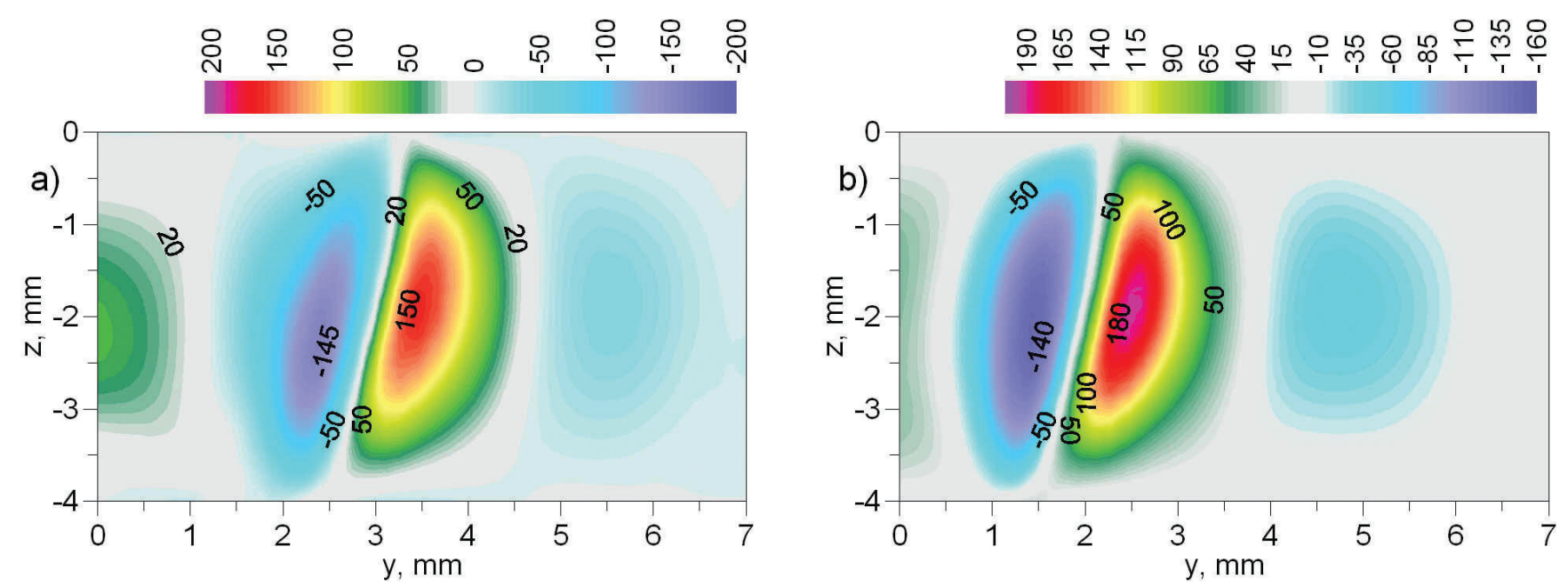

Rys. 11. Rozkłady (mapy) naprężeń poprzecznych $\left(\sigma_{z}\right)$ na przekroju poprzecznym, a) z podgrzewaniem, b) bez podgrzewania

Fig. 11. The distributions (maps) of transverse stresses $\left(\sigma_{z}\right)$ in the cross sections, a) with preheating, b) without preheating
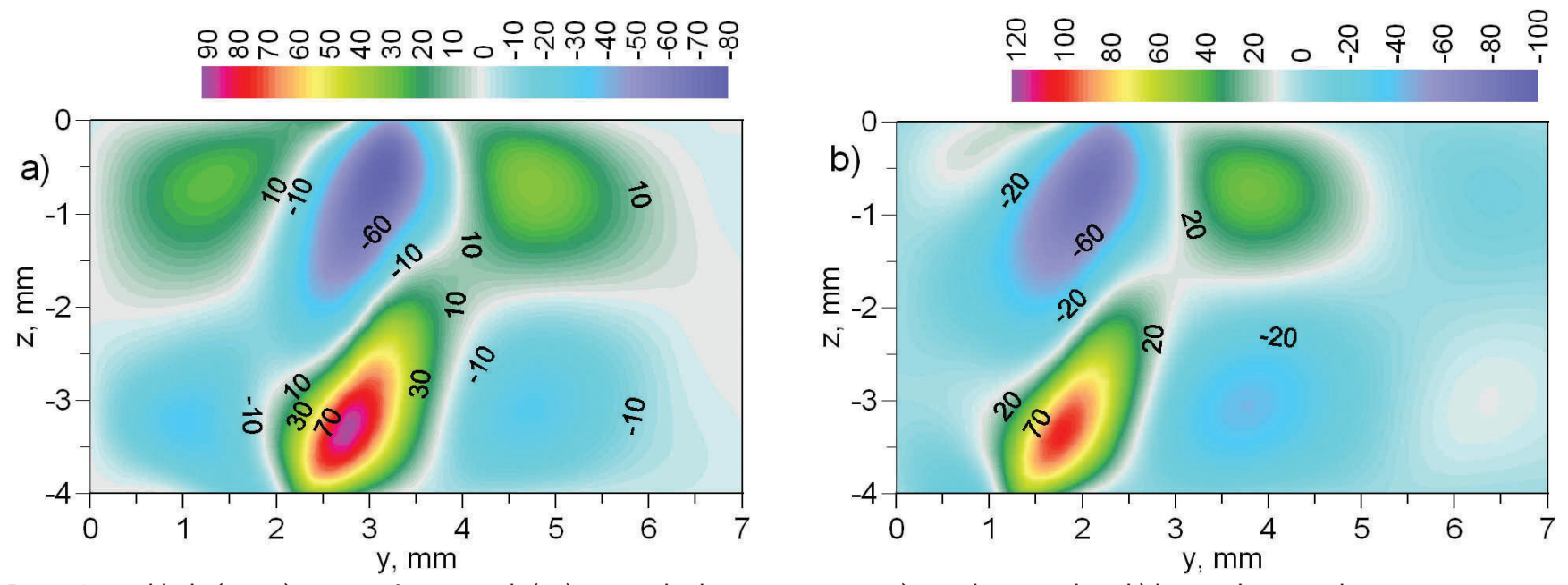

Rys. 12. Rozkłady (mapy) naprężeń stycznych $\left(\sigma_{y z}\right)$ na przekroju poprzecznym, a) z podgrzewaniem, b) bez podgrzewania

Fig. 12. The distributions (maps) of tangential stresses $\left(\sigma_{y z}\right)$ in the cross sections, a) with preheating, b) without preheating

\section{Podsumowanie}

Spawanie laserowe ze wstępnym podgrzewaniem jest korzystniejsze w porównaniu do spawania bez podgrzewania już z punktu widzenia uzyskiwanej struktury w spoinie i strefie wpływu ciepła, ale strefa przetopienia jest szersza w przypadku stosowania podgrzewania wstępnego (rys. 3 i rys. 4). Stosując podgrzewanie, w strukturze spoiny jest mniej martenzytu w porównaniu do ilości martenzytu po spawaniu bez podgrzewania (rys. $5 \div 7$ ), co jest korzystne z punktu widzenia możliwości wystąpienia pęknięć w strefie wpływu ciepła.

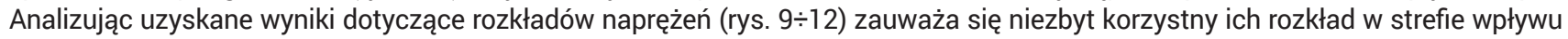
ciepła. Dotyczy to zarówno naprężeń osiowych $\left(\sigma_{x}\right)$, jak i stycznych $\left(\sigma_{y z}\right)$. Naprężenia rozciągające $\left(\sigma_{x}\right)$ występują na całej wysokości (grubości) płaskownika (rys. 10). Może to być powodem pojawiania się pęknięć na granicy spoiny i materiału rodzimego (rys. 9). Bez podgrzewania ma miejsce wyższy poziom naprężeń stycznych (rys. 12), które również mogą przyczynić się do pojawiania się pęknięć, w tym przypadku, pęknięć wewnętrznych. Nieznacznie wyższy jest poziom uzyskanych naprężeń poprzecznych $\left(\sigma_{z}\right)$ w przypadku stosowania podgrzewania (rys. 11). Wiąże się to chyba z większą strefą przetopienia. Na ogół, stosowanie podgrzewania przyczynia się do obniżenia naprężeń spawalniczych, ale różnice w poziomie uzyskanych w przykładach naprężeń nie są tak znaczące, jakich się spodziewano przy zadanych parametrach spawania. Mamy tutaj na myśli dodatkowe koszty związane z podgrzewaniem wstępnym.

\section{Literatura}

[1] M. Melander. A computational and experimental investigation of induction and laser Hardening, Linkoping Studies in Science and Technology, Dissertation No 124, Linkoping 1985.

[2] Y.-N. Liu, E. Kannatey-Asibu: Laser beam welding with simultaneous Gaussian laser preheating. Journal of Heat Transfer, Trans. of the ASME, 115, (1993) pp.34-41.

[3] A. Bokota, W. Piekarska: Modeling of residual stresses in laser welding. The Paton Welding Journal, no. 6 (2008) pp.19-25

[4] W. Piekarska, M. Kubiak, Z. Saternus: Numerical modelling of thermal and structural strain in laser welding process, Archives of Metallurgy and Materials 57 (4) (2012) pp.1219-1227.

[5] V.Ju. Haskin, S.Ju. Pavlovskij, V.P. Garascuk, V.D. Seljagin, E.I. Gonczarenko: Osobennost svarki tonkolistovych nizkouglerodistych stalej impul'snoperiodiceskim izluceniem $\mathrm{CO}_{2}$-lazera. Avtom.Svarka 2001, 2, 42-45.

[6] J. Winczek, E. Gawrońska: The Modeling of Heat Affected Zone (HAZ) in Submerged Arc Welding (SAW) Surfacing Steel Element, Metalurgija, 55(2):225-228, 2016.

[7] В.И. Махненко, Е.А. Великоиваненко, О.В.и др. Махненко: Исследование влияния фазовых превращений на остаточные напряжения при сварке кольцевых стыков труб: Автомат сварка. 2000, №. 5 - С. 3-8.

[8] J. Brózda, J. Pilarczyk, M. Zeman: Spawalnicze wykresy przemian austenitu CTPc-S, Wydawnictwo Śląsk, Katowice 1983.

[9] M. Coret, A. Combescure: A mesomodel for the numerical simulation of the multiphasic behavior of materials under anisothermal loading (application to two low-carbon steels), International Journal of Mechanical Sciences, 44 (2002) pp.1947-1963.

[10] S-H. Kang, Y.T. Im: Finite element investigation of multi-phase transformation within carburized carbon steel. Journal of Materials Processing Technology 183 (2007) pp. $241-248$.

[11] O.C. Zienkiewicz, R.L. Taylor. The finite element method, Butterworth-Heinemann, Fifth edition, vol. 1,2,3, 2000.

[12] L. Taleb, N. Cavallo, F. Waeckel: Experimental analysis of transformation plasticity, International Journal of Plasticity, 17 (2001) pp.1-20.

[13] L. Taleb, F. Sidoroff: A micromechanical modelling of the Greenwood-Johnson mechanism in transformation induced plasticity, International Journal of Plasticity, 19 (2003) pp.1821-1842. 